\title{
Gendered practices of counterinsurgency
}

\author{
LALEH KHALILI
}

\begin{abstract}
Current US counterinsurgency doctrine is gendered diversely in the different geographic locations where it is formulated, put in practice, and experienced. Where Iraqi and Afghan populations are subjected to counterinsurgency and its attendant development policy, spaces are made legible in gendered ways, and people are targeted - for violence or 'nation-building' - on the basis of gender-categorisation. Second, this gendering takes its most incendiary form in the seam of encounter between counterinsurgent foot-soldiers and the locals, where sexuality is weaponised and gender is most starkly cross-hatched with class and race. Finally, in the Metropole, new masculinities and femininities are forged in the domain of counterinsurgency policymaking: While new soldier-scholars represent a softened masculinity, counterinsurgent women increasingly become visible in policy circles, with both using ostensibly feminist justifications for their involvement.
\end{abstract}

Laleh Khalili is a Senior Lecturer in Politics at the School of Oriental and African Studies, the author of Heroes and Martyrs of Palestine: The Politics of National Commemoration (Cambridge, 2007), and a co-editor of Policing and Prisons in the Modern Middle East (Hurst/Columbia University Press, 2010). She is completing a manuscript titled Time in the Shadows: Incarceration in Counterinsurgencies.

\section{Introduction}

Counterinsurgency - defined as asymmetrical warfare by a powerful military against irregular combatants supported by a civilian population - is as old as warfare itself. Although the term itself was coined by John F. Kennedy in 1960 , this particular method of fighting has long been a mainstay of colonial war-fighting and imperial policing. ${ }^{1}$ While a substantial portion of the training, doctrinal development and war-fighting capabilities of European colonial militaries was devoted to this type of war in their overseas colonies, the US Army also accumulated counterinsurgency experience in its colonial expansion westwards which resulted in asymmetric warfare against Native Americans, and their ultimate suppression and circumscription in reservations. ${ }^{2}$

${ }^{1}$ Douglas S. Blaufarb, The Counterinsurgency Era: US Doctrine and Performance: 1950 to the Present (London: Collier Macmillan, 1977); David Galula, Counterinsurgency Warfare: Theory and Practice (New York: Praeger, 1964); Caroline Elkins, Britain's Gulag: The Brutal End of Empire in Kenya (London: Pimlico, 2005); Alastair Horne, A Savage War of Peace: Algeria 1954-1962 (New York: New York Review of Books, 2006 [1977]); Frank Kitson, Low Intensity Operations: Subversion, Insurgency, Peacekeeping (Harrisburg: Stackpole Books, 1971); John Newsinger, British Counterinsurgency from Palestine to Northern Ireland (London: Palgrave MacMillan, 2002); Anthony Short, The Communist Insurrection in Malaya, 1948-1960 (London: Frederick Muller Limited, 1975).

${ }^{2}$ Andrew J. Birtle, US Army Counterinsurgency and Contingency Operations Doctrine 1860-1941 (Washington DC: US Government Printing Office, 1997); also see Stephen W. Silliman, 'The "Old West" in the Middle East: US Military Metaphors in Real and Imagined Indian Country', American Anthropologist, 110 (2008), pp. 237-47. 
As anti-colonial struggles spread across the globe in the wake of the Second World War, counterinsurgency also became a central component of both military war-fighting and social, political, and economic transformations in soon-to-beformer colonies. Even after the 1960s when the majority of former colonies in Asia and Africa had become independent from colonial rule, counterinsurgency continued to be an important element of US military policy in Latin America, and to a lesser extent, elsewhere.

Since the end of the Cold War, counterinsurgency has become more closely associated with a family of other military operations which do not necessarily resemble conventional (usually inter-state) war-fighting. Along with foreign internal defence (that is, provision of indirect aid and military advice and advisors to foreign allies' militaries), stability operations, and reconstruction operations, counterinsurgency is now considered the most significant and frequent form of warfare to be fought across the world and into the future. ${ }^{3}$ As a US Navy strategy document argues, this form of conflict necessitates a partnership between 'governments, non-governmental organizations, international organizations, and the private sector'4 to ensure continued 'stable functioning of the international system' which guarantees the 'core interests' of the US.

Despite the long history of 'small' wars and colonial counterinsurgencies, today's advocates of population-centric counterinsurgency (in which the civilian population is persuaded to defect to the counterinsurgent forces, often counterposed to enemy-centric counterinsurgency which is predicated on the use of violence to deter civilians from cooperating with the insurgents) present it as the 'soft option', especially as compared with scorched earth military tactics where annihilation of the enemy has been the end goal. In the population-centric doctrine advanced in the US Army and Marines Counterinsurgency Manual (FM3-24) and other current classics of counterinsurgency (including John Nagl's Eating Soup with a Knife and David Kilcullen's The Accidental Guerrilla), kinetic force (or the killing capacity of the military) is to take backstage, foregrounding developmental language and agendas such as 'a vibrant economy, political participation, and restored hope', ${ }^{6}$ psychological and information operations, ${ }^{7}$ the use of local proxies, ${ }^{8}$

${ }^{3}$ T. X. Hammes, The Sling and the Stone: On War in the 21st Century (St Paul, MN: Zenith Press, 2006); Robert D. Kaplan, Imperial Grunts: On the Ground with the American Military, from Mongolia to the Philippines to Iraq and Beyond (New York: Vintage Books, 2005); David Kilcullen, The Accidental Guerrilla: Fighting Small Wars in the Midst of a Big One (London: Hurst \& Co, 2009); Daniel Marston and Carter Malkasian (eds), Counterinsurgency in Modern Warfare (Oxford: Osprey Publishing, 2008); John Nagl, Learning to Eat Soup with a Knife: Counterinsurgency Lessons from Malaya and Vietnam (Chicago: University of Chicago Press, 2002); US, Department of the Army, FM3-24: The US Army/Marine Corps Counterinsurgency Field Manual (Chicago: University of Chicago Press, 2007); FM3-07: The US Army Stability Operations Field Manual (Ann Arbor: University of Michigan Press, 2009).

${ }^{4}$ US Department of the Navy, A Cooperative Strategy for 21st Century Seapower (2007), available at: \{http://www.navy.mil/maritime/MaritimeStrategy.pdf\}, pp. 6, 7, accessed on 30 March 2009.

${ }^{5}$ US Army, FM3-07, p. ix.

${ }^{6}$ Ibid., FM3-24, p. 49.

7 Ibid.

${ }^{8}$ Ibid.; Laleh Khalili, 'Tangled Webs of Coercion: Parastatal Production of Violence in Abu Ghraib', in Laleh Khalili and Jillian Schwedler (eds), Prisons and Policing in the Modern Middle East and North Africa (London: Hurst \& Co., 2010). 
and 'the integration of civilian and military efforts' including aid and governance 9 in order to ultimately win over a largely uncommitted civilian population. ${ }^{10}$

This coding of counterinsurgency as the civilisanised option which aims at winning the hearts and minds of civilian populations and persuading them to support the counterinsurgents has a particularly gendered character. What I mean by gendering is a set of practices and discourses that constitute 'men' and 'women' and masculinities and femininities in particular ways. Gendering is neither about women alone, ${ }^{11}$ nor is it a pure and autonomous dichotomy. Rather, masculinities and femininities, especially in imperial contexts, are already always 'cross-hatched' with racial and class designations. ${ }^{12}$

At one level, counterinsurgency itself is presented as the opposite of a more mechanised, technologically advanced, higher-fire-power form of warfare. Given that the latter is often coded as hyper-masculine, the former is considered feminine. Second, the very object of population-centric counterinsurgency would be perceived as feminine, since the focus of counterinsurgency is the transformation of civilian allegiances and remaking of their social world. On the one hand, in the binary categorisation which forms the basis of mainstream discourses about war, civilian (feminine) is the opposite of combatant (masculine). On the other hand those spaces and subjectivities which regular warfare destroys as a matter of sideeffect rather than intent, or which are considered 'collateral' to the main job of war-fighting in conventional warfare, are demarginalised, brought into focus, and, in some senses, made central to the work of military and civilian counterinsurgents. These spaces and subjectivities are perceived by both the military and the civilians as gendered in particular and specific sorts of ways. Finally, the practice of counterinsurgency itself is predicated on 'telling' (combatants from civilians, hostiles from friendlies etc.), ${ }^{13}$ invading, organising, fighting, detaining, transforming, and destroying on the basis of gender (cross-hatched with class and race).

We know from a wealth of scholarship that war and violence have always been gendered, classed and racialised not only in the practical way they are fought but also in the longer term or quotidian manner they shape social relations (and are shaped by them). Moreover, we know that the discursive practices surrounding war also reproduce extant gendered hierarchies through the constant reproduction of a dichotomous rhetoric of masculinities and femininities. ${ }^{14}$ What is new with

${ }^{9}$ William Easterly, 'Foreign Aid Goes Military!', New York Review of Books, LV (2008), pp. 51-4; US Army, FM3-24, p. 54.

${ }^{10}$ For a social-scientific discussion of this process, see Stathis Kalyvas, The Logic of Violence in Civil War (Cambridge: Cambridge University Press, 2006).

11 Joan Scott, Gender and the Politics of History (New York: Columbia University Press, 1988); Denise Riley, 'Am I that Name?' Feminism and the Category of 'Women' in History (Basingstoke: Macmillan, 1989).

12 Anne McClintock, Imperial Leather: Race, Gender and Sexuality in the Colonial Contest (London: Routledge, 1995).

${ }^{13}$ On 'telling', see Allen Feldman, Formations of Violence: The Narrative of the Body and Political Terror in Northern Ireland (Chicago: University of Chicago Press, 1991), pp. 56-9.

14 Terrell Carver, 'Being a Man', Government and Opposition, 41 (2006), pp. 450-68; 'The Machine in the Man', in Jane L. Parpart and Marysia Zalewski (eds), Rethinking the Man Question: Sex, Gender and Violence in International Relations (London: Zed Press, 2008), pp. 70-86; Cynthia Enloe, The Morning After: Sexual Politics at the End of the Cold War (Berkeley: University of California Press, 1993); Bananas, Beaches and Bases: Making Feminist Sense of International Politics, 2nd edition (Berkeley: University of California Press, 2000); Maneuvers: The International Politics of Militarizing Women's Lives (Berkeley: University of California Press, 2000); The Curious Feminist: Searching for 
counterinsurgency is the extent to which the centrality of civilians as potential objects of military operations is acknowledged in doctrine and practice, even (perhaps especially) as civilians are instrumentalised as part and process of the war. ${ }^{15}$ The complex process by which 'civilians' are mapped to particular gender grids, and men and women are 'read' and interpellated according to the constructed notion of 'civilian' is one of the central forms that this counterinsurgency gendering takes. Further, as mentioned above, counterinsurgency doctrine and practice directly bring those bodies and spaces previously coded as 'private' or 'feminine' - women, non-combatant men, and the spaces of the 'home' - into the battlefield; transform cities and homes and persons into highly gendered segments of the 'physical and human terrain'; and utilise detailed knowledge about the quotidian (both perceived and coded as feminine) as 'ethnographic intelligence'. ${ }^{16}$ This conquered and gendered space, in which an indigenous population is controlled, surveilled, monitored, and made to acquiesce, is the first site where I shall analyse gendered practices of counterinsurgency.

In the US 'War on Terror' the gendering of the face-to-face encounter between the US military and the indigenous Iraqi and Afghan populations has been very conspicuous. This is not only the case in the starkly sexualised imagery and practices of interrogation in Abu Ghraib, Guantánamo and elsewhere, ${ }^{17}$ but also in the hierarchies and discourses produced in the context of US forces training indigenous police and military divisions. I call this second site of gendering the seam of encounter, where the "imperial grunts" ${ }^{18}$ - who are the foot-soldiers of the US military, often from lower class backgrounds, frequently belonging to African-American or Latino or non-citizen communities, and sometimes women directly and repeatedly encounter the conquered, whether the latter are those detained and subjected to interrogation or the local proxy security forces being trained by the US military. Here, gendering takes a variety of forms, but most prominent are transformation of sexuality into technologies of coercion, the infliction of abjection via effeminising practices, and the attempt at securing acquiescence through reproducing gendered, raced, and classed hierarchies.

The third site of gendering is the location of production of counterinsurgency policy and doctrine. Here, the gendering of counterinsurgency takes a peculiar

Women in a New Age of Empire (Berkeley: University of California Press, 2004); Cynthia Cockburn, 'The Continuum of Violence: A Gender Perspective on War and Peace', in Wenona Giles and Jennifer Hyndman (eds), Sites of Violence: Gender and Conflict Zones (Berkeley: University of California Press, 2004), pp. 24 44; Carol Cohn, 'Sex and Death in the Rational World of Defense Intellectuals', Signs, 12 (1987), pp. 687-718; “Clean Bombs” and Clean Language', in Jean Bethke Elshtain and Sheila Tobias (eds), Women, Militarism and War (Savage, MD: Rowman and Littlefield Publishers, 1990), pp. 33-56; Zillah Eisenstein, Sexual Decoys: Gender, Race and War (London: Zed Books, 2007).

15 See especially Kilcullen, Accidental Guerrilla.

${ }^{16}$ Helen Kinsella, 'Securing the Civilian: Sex and Gender in the Laws of War', in Michael Barnett and Raymond Duvall (eds), Power in Global Governance (Cambridge: Cambridge University Press, 2005), pp. 249-72; Charli Carpenter, Innocent Women and Children: Gender, Norms and the Protection of Civilians (Farnham: Ashgate Publishing, 2006); Cockburn, The Curious Feminist, p. 35; Michael A. Innes, 'Protected Status, Sacred Sites, Black Holes and Human Agents: System, Sanctuary and Terrain Complexity', Civil Wars, 10 (2008), pp. 1-5; Lt. Col. Fred Renzi, 'Networks: Terra Incognita and the Case for Ethnographic Intelligence', Military Review (2006), pp. 16-24.

17 Tara McKelvey, Monstering: Inside America's Policy of Secret Interrogations and Torture in the Terror War (New York: Carroll and Graf, 2007); Laura Sjoberg and Caron E. Gentry, Mothers, Monsters, Whores: Women's Violence in Global Politics (London: Zed Books, 2007).

18 Kaplan, Imperial Grunts. 
shape. Most strikingly, a new form of masculinity emerges, authorised by consumerism and neo-liberal feminism, in which 'manliness' is softened, and the sensitive masculinity of the humanitarian soldier-scholar (white, literate, articulate, and doctorate-festooned) overshadows the hyper-masculinity of warrior kings (or indeed of the racialised imperial grunts). This concurrent transformation of what masculinity or femininity may mean in the domain of policymaking allows spaces for white middle class women civilians to move into prestigious political positions as counterinsurgents, ${ }^{19}$ all the while casting their own advance as a broader victory for the universal woman.

Even (perhaps especially) here, gendering is never innocent of racial or class hierarchies. Women are increasingly entering the militaries of European and North American nations and becoming further integrated into combat (or combatsupport) roles, ${ }^{20}$ albeit in racialised and hierarchical sorts of ways, while more and more white middle-class women also enter the higher ranks of policymaking. It must be of some significance that three out of four most recent US Secretaries of State have been women; less commented upon has been the increasingly visible presence of women - white, middle-class, educated women - in the US Department of Defense and in security-related think tanks. This rise of a particular category of women, espousing a particular species of feminism, is itself indicative of a kind of femininity which is comfortable with, and in fact positively values, breaking through security spaces coded as masculine, and which appropriates many of the 'new masculine' qualities of the soldier-scholars, perhaps as a subspecies of what Judith Butler has provocatively called drag, or 'an uncritical appropriation of sex-role stereotyping'. ${ }^{21}$ These female security-wonks celebrate work in masculinist policy spaces and with the military as an index of 'having made it', in this case into the often-closed domain of military masculinity.

Furthermore, the space of counterinsurgent intellectuals, consisting of both the soldier-scholars and the women-of-power, considerably overlaps with the epistemic community around humanitarian military interventions. The latter includes a significant proportion of female officials, is coded as feminine work, and enjoys strong and visible advocacy for it by a number of articulate female scholars and policy wonks who move with ease between the academy, think tanks, and policymaking circles.

This article, then, argues that in understanding and critiquing what has happened in all the battlefields of the so-called War on Terror, gender analysis becomes not just a complementary form of analysis but a central one. What I hope to do in this article based on extensive archival and ethnographic research is to examine the gendering of counterinsurgency practices, at the point of making of policy, at the seam of encounter, and at the site of implementation of counterinsurgency, and to critically reflect on the manifold and complex forms of gendering that mutually constitute counterinsurgency practice. I will argue that the confluence

\footnotetext{
${ }^{19}$ Spencer Ackerman, 'Women Prominent in Defense Movement: Seventh Instalment of the Rise of Counterinsurgents', Washington Independent (2008) available at: http://washingtonindependent.com/ 673/women-prominent-in-defense-movement\} accessed on 31 December 2008.

${ }^{20}$ Francine D'Amico and Laurie Weinstein (eds), Gender Camouflage: Women and the US Military (New York: New York University Press, 1999); Erin Solaro, Women in the Line of Fire: What You Should Know about Women in the Military (Emeryville, CA: Seal Press, 2006).

21 Judith Butler, Gender Trouble (New York: Routledge, 1990), p. 174.
} 
of gendering and counterinsurgency practice works to create particular imperial hierarchies in which one's gender does not tell us anything about one's location in the hierarchies, and where different masculinities and femininities can coexist simultaneously if inflected through the lens of racialisation and class.

I use gender here not to stand in for 'women' but as a set of social practices and relations which - intertwined in complex ways with class, 'race', sexuality, and geopolitical location - determine the meaning of 'man' and 'woman'. While sexed bodies bear physiological characteristics that ostensibly distinguish a female body from a male body (but note that even here the social conventions of gender affects the construction and naming of sexes), gender relations define what is masculine or feminine, where particular attributes are said to inhere in 'men' and 'women', and therefore different systems of values can be said to derive from masculine or feminine subjects.

\section{Gendered micro-practices of counterinsurgency in the field}

Because of the centrality of the civilian in counterinsurgency, gender relations are also inevitably transformed as the basis of counterinsurgency action. This works through demographics, through targeting of women specifically as counterbalancing forces to male radicalisation, through the cooptation of gendered spaces to counterinsurgency practice, and the use of gendered 'telling' to distinguish those who are to be protected from those who are to be feared or destroyed.

Gender demographics are here often invoked as both justification for targeting young men, and more instrumentally, for planning military action. 'Youth bulges', a demographic profusion of men between the ages of 15 and 30, especially in Muslim countries, is seen as a structural condition underlying extremism, and as a 'problem' to be addressed militarily in far away places. Young men are seen as an automatically useful resource for radical recruitment, and women's education and job-creation programmes are advocated as 'necessary antidotes'. ${ }^{22}$ This ostensible gender imbalance is utilised to demobilise militant groups. As a former US defence official wrote, 'governments can use groups' ambivalence about female members to state advantage. Israel and Russia use stories of socially marginal women being exploited by men to discredit terrorist groups and explain away female violence'. ${ }^{23}$ A more difficult route to countering the ostensible effects of the youth bulge is through economic development. Like a great deal of social science written in support of US counterinsurgencies in the $1960 \mathrm{~s},{ }^{24}$ the contemporary material about nation-building inherits much from the modernisation theory

22 Lionel Beehner, 'The Battle of the "Youth Bulge"” (New York: Council on Foreign Relations Daily Analysis, 27 April 2007) available at: \{http://www.cfr.org/publication/13094/battle_of_the_youth_ bulge.html\} accessed on 31 March 2009; for a scathing critique see, Göran Therborn, 'NATO's Demographer', New Left Review, 56 (2009), pp. 136-44.

23 Alisa Stack-O'Connor, 'Picked Last: Women and Terrorism', Joint Forces Quarterly, 44 (2007), pp. 95-101.

${ }^{24}$ For an analysis of this category of social science, see Nils Gilman, Mandarins of the Future: Modernization Theory in Cold War America (Baltimore: Johns Hopkins University, 2003) and David Milne, America's Rasputin: Walt Rostow and the Vietnam War (New York: Hill and Wang, 2008). 
advanced by Walt Rostow and his colleagues in the $1960 \mathrm{~s}^{25}$ Here, the salvation stage of liberal democracy requires economic development and one of the most prominent pathways of economic development is the socio-economic advancement of women. ${ }^{26}$ In this literature, women are essentialised as being less corrupt, more efficient, better for economic development, and less warlike. ${ }^{27}$ The feminised security discourse is deployed by all and sundry, and gender mainstreaming becomes even central to military intervention. ${ }^{28}$ Policymakers, for example, argue that by providing economic development specifically to suit women, women can be saved from alienation and thus radicalisation. Women are cast as wholly socio-economic beings, divested of politics or ethics. Under the heading of 'Why the Military Should Care' two US officers, both of them women, suggest that 'by collaborating with USAID and using [Women in Development]'s expertise on gender integration as part of a comprehensive counterterrorism strategy, the military can more effectively address the negative socioeconomic conditions that make areas ripe for terrorist exploitation'. ${ }^{29}$ In a highly influential and muchcirculated set of guidance notes, the counterinsurgency guru David Kilcullen similarly argues that 'coopting neutral or friendly women, through targeted social and economic programmes, builds networks of enlightened self-interest that eventually undermine the insurgents [...] Win the women, and you own the family unit. Own the family, and you take a big step forward in mobilizing the population' on the side of the counterinsurgents. ${ }^{30}$ Thus, advancing women's rights through modernisation is automatically seen as meeting the national security interests of the US. A significant element of counterinsurgency thus becomes provision of social services which are often allocated to women and are seen as another way in which counterinsurgency action can win over a local population into collaboration and loyalty. For example, a Rand analyst (and the wife of Bush Administration official Zalmay Khalilzad) writes that

[h]ealth-care operations have been particularly effective in winning local support [in Afghanistan]. On repeated occasions, female patients in health clinics, thankful for care received and motivated to support the new order that provided it, have volunteered valuable tactical information to US forces. ${ }^{31}$

In the field, counterinsurgency transforms the population it is intended to pacify into a human terrain which can be made visible, knowable, and malleable. The

${ }^{25} \mathrm{~W}$. W. Rostow, The Stages of Economic Growth: A Non-Communist Manifesto (Cambridge: Cambridge University Press, 1960).

${ }^{26}$ A WorldBank study of women's empowerment shows that much of the literature on empowerment was actually more interested on how empowerment of women affected other development indicators: Anju Malhorta, Sidny Schuler and Carol Boender, 'Measuring Women's Empowerment as a Variable in International Development' (Washington DC: World Bank, background paper, 2002), p. 23.

27 Cheryl Bernard et al., Women and Nation-Building (Santa Monica: RAND Corporation, 2008). On corruption and efficiency, see David Dollar, R. Fisman, and R. Gatti, 'Are Women Really the "Fairer Sex"? Corruption and Women in Government', Journal of Economic Behavior and Organization, 46 (2001), pp. 423-29.

${ }^{28}$ Lieutenant Colonel Miemie Winn Byrd and Major Gretschen Decker, 'Why the US Should Gender Its Counterterrorism Strategy', Military Review (July-August 2008), p. 96.

29 Ibid., p. 100.

${ }^{30}$ David Kilcullen, “Twenty-Eight Articles": Fundamentals of Company Level Counterinsurgency', Military Review (May-June 2006): pp. 103-8.

31 Bernard et al., Women, p. 13. 
Human Terrain System (HTS) of the US military, for example, couples military officers with social scientists who are to interview the local populations, to understand not only their needs and wants, but also their kinship structures, the peculiarities of their gender relations, their way of living, their relationship with others around them, and beyond. ${ }^{32}$ These specifically gendered structures of life are reified, fixed in time and space, mobilised as 'useful facts' about the civilian population, and transformed into military intelligence. For example, a paper produced by the Human Terrain System's research unit is specifically named after gendered kinship structures, 'My Cousin's Enemy Is My Friend', arguing that

rural Pashtuns have well-developed methods to resolve conflicts through jirga mediation and the exchange of property or women.

The result of this special kind of intra-family relationship is that, during times when conflicts aggravate first-cousin hostility, the sides don't necessarily break down along 'closest male relative' lines. Whereas in a classical Middle East tribal situation, all the participants in a conflict pick sides based on which side represents their closest male relative, Pashtuns establish temporary factional groupings that are unpredictable and not necessarily based on familial relationships. ${ }^{33}$

Here, Pashtun kinship ties are taken as timeless facts to be contrasted to some idealised, homogenous, equally timeless 'classical Middle Eastern tribal situation' even as the paper again and again indicates that 'tribal' structures can and do vary across time and space. In both Iraq and Afghanistan, gender, familial, and kinship ties are seen as the bases of military strategy, whereby, different tribal structures can determine whether or not 'surges' of troops can be effective. ${ }^{34}$

Just as important, the very sites of counterinsurgency are usually civilian spaces that are then walled off (both figuratively and literally) as a sub-section of the battle-space, a grid square that can be more easily pacified. In counterinsurgency, all spaces, and perhaps especially urban quarters, are seen as potential battlegrounds by the counterinsurgents. The conventional privacy measures for homes and the peacefulness of everyday spaces are no longer guaranteed. Spaces often not only coded as feminine but also considered women's domain (homes, hospitals and schools especially) are frequently invaded by counterinsurgents. ${ }^{35}$ These 'private' or civilian spaces - the home, the school, the hospital, the market, the village - are increasingly targeted in modern wars, and in fact were specifically the object of intense bombing in conventional warfare in the twentieth century. What counterinsurgency does, however, is to try to transform these spaces without necessarily destroying them (although destruction - especially in the wake of population resettlement is often inevitable), thus coopting everyday spaces into the landscape of war. Inevitably, these everyday landscapes are inhabited by civilians who are also made to be figures in the ongoing counterinsurgency. The utilisation of these

32 AAA Commission on the Engagement of Anthropology with the US Security and Intelligence Communities (CEAUSSIC), 'Final Report on The Army's Human Terrain System Proof of Concept Program' (14 October 2009) available at: \{http://www.aaanet.org/cmtes/commissions/CEAUSSIC/ upload/CEAUSSIC_HTS_Final_Report.pdf $\}$ accessed on 21 December 2009.

33 TRADOC G2 Human Terrain System, 'My Cousin's Enemy is My Friend: A Study of Pashtun "Tribes" in Afghanistan' (Ft Leavenworth: US Army Training and Doctrine, Afghanistan Research Reachback Center White Paper, 2009), p. 10.

34 TRADOC G2 HTS, 'My Cousin's Enemy', p. 5.

35 Eyal Weizman, 'Waking through Walls: Soldiers as Architects in the Israeli-Palestinian Conflict', Radical Philosophy Review, 136 (2006), pp. 8-22. 
spaces in counterinsurgency is directly and intimately tied up with the ways in which counterinsurgency practice makes men and women legible and assigns them to different categories of various utility for combat and pacification.

Because counterinsurgency requires the categorisation of population into combatants and non-combatants, and because the easiest way to quickly identify and categorise populations as high-risk combatants or low-risk civilians is by gender, the combatant/non-combatant distinction becomes fully gendered, where the all-encompassing suspicion against all men is operationalised into specific actions (to be discussed below), while women are afforded the status of being 'naïve' objects of 'protection', pacification, and humanitarian salvage. We already know that this gendering produces a 'masculinist logic of protection', ${ }^{36}$ and that the object of military intervention, humanitarian aid, and primary focus of concern in a post-conflict environment becomes an undifferentiated 'womenandchildren'. ${ }^{37}$ What counterinsurgency does is to transform the 'womenandchildren' into either actors considered by the counterinsurgent to be complicit with the combatants, a terrain upon whom the counterinsurgency's social engineering experiments can be performed, or, increasingly, as hostages and literal or symbolic message-bearers for the work of counterinsurgency. Importantly, given the paucity of distinguishing features between civilians and combatants, the gendered process of telling 'womenandchildren' from others becomes central to targeting processes in counterinsurgencies. ${ }^{38}$

In 2004, for example, a large number of Iraqi cities were either surrounded by barbed wire, under constant monitoring, or both. House invasions were often the norm. In these circumstances, women became direct targets of violence. They were taken as hostages to compel the men to surrender, ${ }^{39}$ their homes were destroyed, and they were specifically targeted because of a purportedly intuitive understanding of the enormity of attacking women and the ways in which such targeting could 'send a message' to others. ${ }^{40}$ In one instance, the US

soldiers came to the house of an Iraqi man suspected of hijacking trucks. He wasn't there, but his wife and two other women answered the door. 'You have 15 minutes to get your furniture out,' First Sgt. Ghaleb Mikel said. The women wailed and shouted but ultimately complied, dragging their bed and couch and television set out the front door. Mikel's men

36 Judith Hick Stiehm, 'The protected, the protector, the defender', Women's Studies International Forum, 5 (1982), pp. 367-77; Ann Tickner, Gendering World Politics: Issues and Approaches in the Post-Cold War Era (New York: Columbia University Press, 2001); Iris Marion Young, 'The Logic of Masculinist Protection: Reflections on the Current Security State', Signs, 29 (2003), pp. 1-25; Kinsella, 'Securing the Civilian'.

37 Enloe, Morning After, p. 166.

38 An extreme instance of the gender segmentation of civilian victims could be observed during the Israeli assault upon Gaza in 2008/2009 when most media outlets tallying the casualties of the Israeli attack only counted 'womenandchildren' as 'innocent' victims, and men were automatically excluded from such rosters of victimhood and trauma by the fact of their sex. An even more extreme instance of the counterinsurgency cooptation of women and children as possibly complicit with the insurgents is Alan Dershowitz's defence of Israeli military's violence against civilians, where only babies are considered to be rightfully civilians. See, Alan Dershowitz, "Civilian casualty"? That's a gray area', Los Angeles Times (22 July 2002); also see Alice Hills, 'Hearts and Minds or Search and Destroy? Controlling Civilians in Urban Operations', Small Wars and Insurgencies, 13 (2002), pp. $1-24$.

39 S. G. Mestrovic, The Trials of Abu Ghraib: An Expert Witness Account of Shame and Honor (Boulder: Paradigm Publishers, 2007), p. 124.

${ }^{40}$ Cecilia M. Bailliet, "War in the Home": An Exposition of Protection Issues Pertaining to the Use of House Raids in Counterinsurgency Operations', Journal of Military Ethics, 6 (2007), p. 185. 
then fired four antitank missiles into their house, blowing it to pieces and setting it afire. The women were left holding their belongings [. . .] At a news conference in November 2003, Sanchez, the top commander in Iraq, acknowledged that he had authorized the destruction of homes thought to be used by insurgents. That same month, American officers said they detained the wife and daughter of Gen. Izzat Ibrahim, a high-ranking member of Hussein's government who was still at large. The hope, they said, was that the women could lead them to Ibrahim. ${ }^{41}$

Men are differentially targeted in these wars. In the cordoned cities where retinal scans, thumb prints, identity cards and registers of residence are used to monitor the populations, ${ }^{42}$ men between the ages of 15 or 16 and 50 are considered the primary target of this intensive, aggressive, and invasive surveillance. ${ }^{43}$ As a US military oral history of Falluja recounted,

One of our biggest challenges [...] was who do you let out and who do you not? What are the rules and the screening procedures? And when they're let out, where do they go? So the bottom line answer was that military-aged men, defined as 16 to 55, would not be permitted to leave, but children and women certainly could leave. We had all the Marines and soldiers fully understanding those rules and how you were to search people before they'd be let out. So one of the tasks we faced was this 'humanitarian' task of folks that want to flee this unbelievable combat environment. How you do that so you didn't put your soldiers at risk and you didn't let a key target out? ${ }^{44}$

But despite their assertions, even young boys were not exempted from suspicion and monitoring. A re-evaluation of the fighting in Falluja by a military official asserted that

Insurgents blended into the civilian population and forced or persuaded civilians to assist them. Iraqi children made roadblocks, served as messengers, and manned Ops. One military AAR [After Action Review] notes that boys lugged mortar shells to insurgent positions. ${ }^{45}$

This targeting of men also conveniently serves another function. It allows for the soldiers to specifically effeminise the men of the population through both symbolic and practical emasculation. Such tactics include the undressing of men at checkpoints and in prisons and the use of language which is intended to dishonour men. This partially comes out of an orientalist understanding of what is considered honourable or shameful in 'Muslim culture' and which presents this culture's notions of indignity and abuse as exceptional. ${ }^{46}$ As a former US military interrogator recounts, the interrogators' cultural training, based on the infamous The Arab Mind by Rafael Patai, included such admonitions as 'Men should not touch Arab women - female soldiers should avoid touching Arab men', ${ }^{47}$ thus

${ }^{41}$ Dexter Filkins, 'The Fall of the Warrior King', New York Times Magazine (23 October 2005).

42 Charles Levinson, 'Fallujah Safer but Residents Still Lack Basic Services', USA Today (24 January 2008).

43 On the targeting of men, see Adam Jones (ed.), Gendercide and Genocide (Nashville: Vanderbilt University Press, 2004).

44 Colonel Michael Formica (21 April 2006) quoted in Kendall D. Gott, Eyewitness to War, Volume 1: The US Army in Operation Al-Fajr, an Oral History (Fort Leavenworth: Combat Studies Institute Press, 2006), p. 33.

45 Sean A. Edwards, Complex Environments: Battle of Fallujah I, April 2004 (Fort Belvoir, VA: US Army National Ground Intelligence Center, 2006), p. 12.

${ }^{46}$ See a critique of this idea in Jasbir Puar, 'Abu Ghraib: Arguing against Exceptionalism', Feminist Studies, 30 (2004), pp. 522-34.

47 Tony Lagouranis and Allen Mikaelian, Fear Up Harsh: An Army Interrogator's Dark Journey through Iraq (New York: NAL Caliber, 2007); on Patai, see Edward Said, Orientalism (New York, Vintage Books, 1978), pp. 308-9. On the US military's use of Patai, see Patrick Porter, Military 
casting sexualised abuse as particularly abhorrent to Arabs, and in a sense reproducing orientalist gender stereotypes about the objects of counterinsurgency.

More broadly and perhaps in a less directly intentioned way, the requirements of counterinsurgency re-engineer the gendering of economic relations. Maya Rosenfeld's illuminating ethnography of the Deheisheh Palestinian refugee camp in the West Bank shows that because of the strict limits placed on the movement of men, their ability to find jobs is severely curtailed. As women are subjected to a slightly less severe regime of controls, they can more easily find jobs, and keep their jobs. As such, the burden of labour is either shifted to women in a family (and sometimes even to the daughters in a family) or more equally divided, inevitably shifting the grounds of gender in particular ways that are not always positive. ${ }^{48}$ Working women who are forced to fend for their families under conditions of war and occupation - rather than a slow social transformation and self-sustaining mobilisation - are subjects of gossip, their youthful leisure is heavily circumscribed, their possibilities of further education is curtailed, and their labour is often exploited much more extensively. The men who have been thus sidelined suffer from depression and a loss of identity, and find themselves displaced. Because of necessity, such re-engineering also transforms unemployed men into willing conscripts into burgeoning security forces which often appear in such conditions of occupations, thus structurally reproducing the conditions of conflict.

\section{The seam of imperial encounter}

A more complicated set of gendering practices occurs not at the endpoint of application of counterinsurgency force, but at the seam of encounter between the occupying military forces and the people subjected to counterinsurgency. This seam is the messy interstitial space in which the cross-hatching of race, gender, class, and empire all produce unexpected hierarchical positioning.

Here, two groups in particular stand out: the women from the invading and occupying military and the local men who serve as the proxy enforcers of order for the invading military.

In the first instance, the displacement of inequalities to a neo-colonial setting suddenly inverts orders of hierarchy, and women from disadvantaged backgrounds can suddenly become powerful players positioned against and above local males. This inversion of hierarchies is reinforced by representing the arrested and incarcerated men as rapists and of the local male population as oppressors of their wives and families. ${ }^{49}$ As Anne McClintock has written in a different context,

The vast fissured architecture of imperialism was gendered throughout by the fact that it was white men who made and enforced laws and policies in their own interests.

Nonetheless, the rationed privileges of race all too often put white women in positions of decided - if borrowed - power, not only over colonized women but also over colonized men. As such, white women were not the hapless onlookers of empire but were

Orientalism: Eastern War through Western Eyes (London: Hurst \& Co., 2009), pp. 60-1.

${ }^{48}$ Maya Rosenfeld, Confronting the Occupation: Work, Education, and Political Activism of Palestinian

Families in a Refugee Camp (Palo Alto: Stanford University Press, 2004).

${ }^{49}$ McKelvey, Monstering, p. 103. 
ambiguously complicit both as colonizer and colonized, privileged and restricted, acted upon and acting. ${ }^{50}$

The peculiarities of this positioning, where working class women from the least privileged parts of the US found themselves in positions of power vis-à-vis Iraqi men, has been best personified in the narratives about Lynndie England and Sabrina Harman. England and Harman have become iconic figures, symbolising the torture inflicted upon Iraqi men in the Abu Ghraib prison. The former held a leash encircling the neck of a naked Iraqi man curled up into a vulnerable foetal position; the latter had herself photographed smiling cherubically and giving a thumbs-up sign while leaning close to the dead body of a visibly bruised and battered Iraqi general. The US prison guards and interrogators who had inflicted pain upon Iraqi captives never managed to generate the same sense of disgust as England and Harman; they were never made the archetypes of US torture, nor their names were came to be known as universally as the two figures above. Not only were England and Harman the iconic representations of transgressive women, they were also subtly the embodiment of a new hierarchy of power, in which white women were automatically placed in superior position to men who in other circumstances would have been the expected superiors (as an Iraqi general's class position would be more privileged than that of a daughter of a police detective, Harman, or a poultry factory worker, England).

In the instances where women have been used as interrogators, their bodies and their sexuality have been deployed as technologies of power. In one of the most disturbing accounts of interrogations at the Guantánamo Bay prisons, a male interrogator writes about female interrogators using their breasts, their bodies, and their menstrual blood as necessary tools for achieving dictated aims. The narrative recounted is long, but strikingly persuasive in this regards:

We returned to the [interrogation] booth. Brooke [female interrogator] and I were both in our sanitized (our names were taped over) BDUs [battle-dress uniform]. To my surprise, she started to unbutton her top slowly, teasingly, almost like a stripper, revealing a skin-tight brown Army T-shirt stretching over her chest.

Fareek [the Saudi prisoner] wouldn't look at her. 'What is the matter, Fareek? Don't you like women?' As she said this, she stood in front of him and tried to make him look at her body. She walked slowly behind him and began rubbing her breast against his back. 'Do you like these big American tits, Fareek?' She said [...]

'What do you think, Fareek?' she said, placing her hands on her breast [...] He glanced, saw what she was doing, and immediately looked away.

'Are you gay? Why do you keep looking at him?' Brooke asked, referring to me [...]

She started unbuttoning her BDU pants. 'Fareek, did you know that I'm having my period?' she said. She placed her hands in her pants as she started to circle behind the detainee. 'How do you feel about me touching you now?' [...]

Brooke came back around his other side, and he could see that she was beginning to withdraw her hand from her pants. As it became visible, the Saudi saw what looked like red blood on her hand [...] 'You fuck,' she hissed, wiping what he believed was menstrual blood on his face [...]

'What do you think your brothers will think of you in the morning when they see an American woman's menstrual blood on your face?' Brooke said, standing up. 'By the way, we've shut off the water to your cell tonight, so the blood will still be there tomorrow'. ${ }^{51}$

${ }^{50}$ McClintock, Imperial Leather, p. 6.

${ }^{51}$ Erik Saar and Viveca Novak, Inside the Wire: A Military Intelligence Soldier's Witness Account of Life at Guantánamo (New York: The Penguin Press, 2004), pp. 223-8; See also, Paisley Dodds, 'Sex 
The uncritical self-abnegation of the white interrogator woman in the service of some nationalist understanding of 'national security' is part of the peculiar gendering of counterinsurgency practices. In conventional wars where laws of war and the Geneva Conventions apply, such interrogations would not, could not, happen with the degree of legitimacy and sangfroid which seemed to have happened in the War on Terror.

Jessica Lynch's narrative similarly served to reproduce the hierarchies in which the Iraqis were portrayed as barbarians. ${ }^{52}$ Here, she was at once the heroic white woman rising well above the savage men who captured her (and possibly raped her, as some accounts have had it), and a damsel in distress whose rescue by even more heroic Special Forces men again instantiated the virtuous superiority of the invaders over the depraved occupied men. Interestingly, race here plays a multiple role, because as others have shown, the four men and the other woman who were also captured at the same time could not serve as the iconic representations of American virtue in the same way. A woman's body was needed, and a white one: the other captured woman was a 'black single mother [...], a body already marked as illegitimate within the USA's racialized politics, and indeed a body marked as not even worth saving in the recasting of the story'. ${ }^{53}$

A much more banal representation of this seam of encounter, and perhaps in many respects more important because more pervasive, has been the ease with which women have moved into combat roles, serving the empire unquestioningly, with their integration into these roles being celebrated as some form of liberationist politics. A (male) Lieutenant Colonel in the Army writes

[o]n any given day in Iraq, an American soldier might be asked to search travellers at a roadside check point, comfort distraught mothers whose children have been killed or injured, search a woman's quarters in a strictly Islamic household, or assist civilians whose homes have been destroyed. Given the traditional role of women as peacekeepers and humanitarians in their own homes, is it not illogical to believe that a woman could perform each of these tasks as well, if not better. ${ }^{54}$

Thus, a gendered body becomes a necessary, indeed desired, adjunct or accessory to an asymmetrical war of conquest and occupation. The gendered body serves the functions of counterinsurgency - the 'humanitarian', ostensibly 'softer', tasks that are required to ensure the winning of hearts and minds - much more efficiently and effectively. Celebratory accounts of such integration, ${ }^{55}$ or even critical analyses which see the participation of women in acts of collective violence as an instantiation of agency, ${ }^{56}$ ignore the fact that the equal opportunity to enter combat in the service of empire does not necessarily have agential or liberatory functions. When 'women join men in the work of objectifying and psychologically

Used to Break Muslim Prisoners, Book Says', Associated Press (28 January 2005).

52 Deepa Kumar, 'War Propaganda and the (Ab)uses of Women: Media Constructions of the Jessica Lynch Story', Feminist Media Studies, 4 (2004), pp. 302-3.

${ }^{53}$ Cristina Masters, 'Femina Sacra: The "War on/of Terror", Women and the Feminine', Security Dialogue, 40 (2009), pp. 36-7.

${ }^{54}$ Lt. Colonel Henderson Baker, 'Women in Combat: A Cultural Issue?' (Carlisle Barracks: US Army War College Master's Thesis, 2006), p. 10.

55 See the jarring contribution by Solaro to an otherwise critical edited volume: Erin Solaro, 'Women and the Profession of Arms', in Tara McKelvey (ed), One of the Guys: Women as Aggressors and Torturers (Emeryville: Seal Press, 2007), pp. 97-110; also Solaro, Women; Kayla Williams with Michael E. Staub, Love My Rifle More Than You: Young and Female in the US Army (London: Phoenix Press, 2005).

56 Sjoberg and Gentry, Mothers, Monsters. 
annihilating the "enemy", finding ways to "effeminize" him, if he is a man'57 they essentially help reproduce a geopolitical dominance in which the ostensible gender equality in the imperial metropole reinforces racial hierarchies in the conquered and occupied colonies and peripheries.

A second space in the seam of encounter where genders are inflected through racial, class, or imperial hierarchies is the site of encounter between the US military men and the local security forces who act as proxies for the conquering military. ${ }^{58}$ Training and developing indigenous police and military forces is a central tenet of counterinsurgency. The tasks here include 'developing a US-style training base, embedding advisors, initiating an intensive collective training programme, and partnering American units with indigenous units'. ${ }^{59}$ Yet the local men, who often risk opprobrium, and who often join the security forces as a way of guaranteeing a livelihood in conditions where security is the only steady sort of income, are constantly berated, 'effeminised', called 'women' or 'pussies', and seen as inadequate and passive enforcers of good order by their trainers.

Here, masculinity alone does not form the basis of transnational solidarity, and again, gender hierarchies are strongly shaded by other factors, such as 'class, "race"/ethnicity, language and religion, subcultures, sexualities and almost any other form through which humans understand difference, and strive to make it count' ${ }^{60}$

According to this logic, if a member of the local security forces does not fight a war to which he does not necessarily have an allegiances, his manhood is considered to be impaired. In an account of the US assault on Falluja, a commander of the 1st Marine Regiment considers Iraqi policemen and Civil Defense Corps troops who fled the devastation of that city to be inferior and effeminised: 'When are these people going to discover their manhood and stand and fight with us to save their city?' ${ }^{\prime 1}$ In this view, working for an occupying force is what allows a man his masculinity, but sometimes even this acquiescence to domination does not suffice. Where more circumspect officers speak of a lack of maturity for an indigenous security force which does not perform as the imperial military expects it, ${ }^{62}$ videos circulating on online sites have shown a much more overtly gendered conversation between a US Marine trainer and Iraqi security forces. The former questions the loyalty of the latter, and then calls them 'bunch of women', 'pussies', and 'cowards', 'too much of a fucking woman to die for his country', lacking a backbone and yet 'killing Americans' and refusing to fight insurgents. When an Iraqi sneers at him, the marine challenges him to 'going out back and having his little ass being beaten'. ${ }^{63}$

${ }^{57}$ Lynne Segal, 'Gender, War, and Militarism: Making and Questioning the Links', Feminist Review, 88 (2008), p. 33.

${ }^{58}$ Lt. General James Dubik, Best Practices in Counterinsurgency. Building Security Forces and Ministerial Capacity: Iraq as a Primer (Washington DC: Institute for the Study of War, 2009).

${ }^{59}$ Matthew W. Markel, 'Building Partner Security Forces: Sometimes War Is the Answer', The Joint Forces Quarterly, 42 (2006), p. 76.

${ }^{60}$ Carver, 'Being a Man', p. 456.

${ }^{61}$ Alissa Rubin and Doyle McManus, 'Why America Has Waged a Losing Battle on Fallouja', Los Angeles Times (24 October 2004).

${ }^{62}$ Markel, 'Building'.

63 'Lazy Iraqi Police get motivational speech', available at: \{http://www.youtube.com/watch?v= rlGrdTakv18\} accessed on 21 December 2009. 
In a context where a proxy force fights for an imperial one, the gendering of these proxy forces can take two different paths, which nevertheless share common characteristics. On the one hand, the colonial discourse surrounding 'martial races' envisioned fighters in the service of empire who are 'naturally' fiercer fighters, more disciplined and fearless warriors, and thus far more masculine in their bearing and representation. The Kenyan Masai, the Nepalese Gurkhas, the Afghan Pathans (or Pashtuns), the Indian Sikhs, and the Scottish Highlanders have all been considered martial races. Heather Streets writes,

In the Indian Army, the codification of groups according to their status as 'martial' or 'non-martial' was part of a concerted strategy to limit military service to the select few who could be trusted to remain undyingly loyal to the Raj. By contrast, in the British Army the identification of Highlanders as martial races was meant to widen the popular appeal of the army and to challenge both feminist claims of sin and degradation in the army and wider concerns about the racial degeneration of British men. ${ }^{64}$

The other way in which such colonial war-fighting is gendered is through the effeminisation of the colonised man. Here, as McClintock writes with regards to Africans, 'the white race was figured as the male of the species and the black race as the female', while elsewhere, 'imperial conquest was [seen] as a natural expression of masculinity' which then meant that the conquered were naturalised as feminine, conquered, penetrated, and possessed. ${ }^{65}$

Although this may seem in the first glance contradictory, a certain set of familiar tropes actually connect the two discourses to one another: a notion of loyalty to the conquering empire representing a degree of masculinity, the necessity to distinguish the 'the proper man and the dissipated unmanned', ${ }^{66}$ and a distinct conflation of masculinity with particular notions of sexuality. As Levine has shown the 'oversexed native' who lacks courage, independence, and moral vigour - all masculine virtues - is portrayed as 'the polygamist, the masturbator, the whorer, and the sexually fluid' ${ }^{67}$ Loyalty and military service to the empire is intended to redeem him from this moral degeneracy. In the context of the War on Terror, the men who are located in the seam of encounter are cast in these seemingly contradictory ways: they can be at once courageous and manly allies and sodomising homosexual rapists. A particularly revealing account from a former US military man stationed in Afghanistan contains all the relevant tropes:

Homosexuality was pervasive among the Afghans, especially the Pashtuns in the south. Even when they weren't overtly engaged in acts of sex, they would cling to each other, hold each other's hand, and generally cavort in ways that would astonish Westerners and repulse soldiers. Some of the marines would laugh incredulously. Others would be moved to violent reactions. In one case, Fitzgerald watched a gigantic marine march furiously toward two coupled Afghans and pick them up and toss them in different directions like dogs, yelling the whole time in English the Afghans couldn't understand. The 'female' of the two scurried away. The dominant male was sort of indignant and flipped his scarf over his shoulder and walked off. ${ }^{68}$

${ }^{64}$ Heather Streets, Martial Races and Masculinity in the British Army 1857-1914 (Manchester: Manchester University Press, 2004), p. 173.

${ }^{65}$ McClintock, Imperial Leather, p. 55; also see Philippa Levine, Prostitution, Race and Politics: Policing Venereal Disease in the British Empire (New York: Routledge, 2003), p. 257.

66 Levine, Prostitution, p. 259.

67 Ibid., pp. 263-4.

${ }^{68}$ Chris MacKey and Greg Miller, The Interrogator's War: Inside the Secret War against Al Qaeda 
The Pashtun - or the warrior allies - in this narrative are compared to 'dogs' and effeminised not only because of the sexual acts of which the masculine US marines disapprove, but also because they hold each other's hand and 'repulse' Westerners with their homosociality. Even the story, as it told, draws on masculine and feminine images: a 'gigantic Marine' stands for unspoiled American masculinity, while an 'indignant' Pashtun 'flipped his scarf' over a shoulder, invoking clichéd imagery of petulant teenage girls flipping their hair in exasperation.

The seam of encounter then is the place where class, race, and gender are brought together most urgently, with masculinities always hitched to a particular kind of sexuality, and an iterative ordering of hierarchies is constantly performed. Here, underprivileged working class women of the US can transcend the shackles of their gender and class, as long as they weaponise their own bodies and sexualities, and where indigenous men are made to 'know their place' in this hierarchy via a strictly observed code of behaviour which always sees them as effeminate, degenerate, cowardly, and backwards, unless - but often not even when - they throw their lot in with the occupying military, serving them as local police forces.

\section{The counterinsurgent women and the soldier-scholars of the metropole}

While gendering works in familiar, even predictable, ways in the conquered spaces and at the seam of encounter between counterinsurgency forces and the indigenous men and women, gendering of counterinsurgency becomes much more fluid and sometimes unpredictable in the metropole, where policies are formulated, ideologies are articulated, and wars are planned and legitimated.

Two ways in which counterinsurgency practice and discourse has become gendered in the metropole have been most striking: on the one hand, the creation of a new counterinsurgent masculinity - that of the soldier-scholar - and on the other hand, the appropriation of a colonial feminist discourse and its saturating of counterinsurgency discourse by women bureaucrats and policymakers who explicitly elide their counterinsurgency credentials to their gendered identities.

In analysing masculinities, Terrell Carver has written that 'the rationalbureaucratic modern man is not so distant from the warrior-protector man of tradition, in that organized warfare and organized trade are not as conceptually, constitutively and practically distant as one is led to think. Indeed, in terms of the revolving doors between government officials (elected and non-elected) and the arms trade and so-called defence industries, combined with the technologized nature of contemporary "civilized" warfare (as opposed to supposed "terrorism"), it would seem that the two masculinities are effectively merged'. ${ }^{69}$ In a sense, this applies to the soldier-scholar masculinity as well, but as important are the subtle transformations and differences in the notion of masculinity that class brings in.

The soldier-scholars are numerous and now well-known. They are also overwhelmingly represented in the ranks of the counterinsurgents. David Petraeus

\footnotetext{
(London: John Murray, 2004), p. 186; also see Kevin Burke, Civil Reconnaissance: Separating the Insurgent from the Population (Monterey: Naval Postgraduate School, 2007).

${ }^{69}$ Carver, 'The Machine', p. 78.
} 
(PhD in International Relations), David Kilcullen (PhD in Political Science), John Nagl (PhD in History), H. R. McMaster (PhD in History), and Andrew Exum (a soon-to-be-completed PhD in War Studies) are all vocal, articulate, and highly educated military (or ex-military) men, all of whom are ranked above captain, all of whom are engaged in policymaking vis-à-vis the War on Terror, and all of whom are enthusiastic counterinsurgents. Some have written influential books and articles on counterinsurgency, others have been online or think tank presences pushing forward a counterinsurgency agenda, while Petraeus first directed the US war effort in Iraq and now leads the US Central Command. The soldier-scholars all advance a notion of war-fighting which ostensibly takes into account political nuances, aims to win over civilian populations, and deploys an openly liberal discourse of salvation and humanitarianism. Not only is the soldier-scholar the ultimate in civic virtue, he is also the embodiment of international wisdom, war-fighting prowess, and a kind of knowingness about the world. ${ }^{70}$ This transformation in the notion of masculinity is reflected in blogs and ad hoc writing produced about counterinsurgency. The counterinsurgents want to be 'soldiers' and find the term 'warrior' troubling. Thus, when Nathan Sassaman calls himself 'the Warrior King', he and his book are roundly criticised by the counterinsurgents. ${ }^{71}$

Even the official discourse around counterinsurgency reflects this shift. The US Army and Marine Corps' counterinsurgency field manual compares a regular fighter to that ultimate icon of raw physical masculinity: a pugilist who is nevertheless blind and is wasting energy flailing at unseen opponents and perhaps causing unintended harm. ${ }^{72}$ Access to military intelligence, on the other hand, transforms the counterinsurgent into 'surgeons cutting out cancerous tissue while keeping other vital organs intact'. ${ }^{73}$ On the one hand, we have the wholly corporeal presence of the boxer; on the other, the precise intellect of the surgeon. The theoreticians of counterinsurgency obviously prefer the latter. Not only does this counter-positioning of boxers and surgeons contain an implicit notion of masculinity, perhaps even more importantly, it hides within plain sight a particular gradation of class. The boxer is the working class hero; the surgeon the upper middle class professional. The former is emotional, embodied, perhaps even irrational; the latter is intellectual, cool, steady-handed.

The soldier-scholar is particularly well-suited to the liberal interventionist model which sees its job as cautiously and pragmatically doing the biddings of the US national interest. Soldier-scholars are not interested in chest-thumping gestures, deploy the language of 'hearts and minds' much more readily and see their wont as being the wielders of softer or smarter power. Old school warriors see counterinsurgency and the entire family of stability operations to which it belongs as a diminishment of the inherent masculinity of the military:

${ }^{70}$ Also see, R. Claire Snyder, Citizen-Soldiers and Manly Warriors: Military Service and Gender in the Civic Republican Tradition (Lanham, MD: Rowman \& Littlefield, 1999).

${ }^{71}$ Nathan Sassaman and Joe Layden, Warrior King: The Triumph and Betrayal of an American Commander in Iraq (New York: St. Martin's Press, 2008); Thomas E. Ricks, 'Fight Club: Excessive force nearly lost us the Iraq War. The brass who gave the orders still don't get it', The Washington Monthly (Aug/Sep/Oct 2008), available at: \{http://www.washingtonmonthly.com/features/2008/0808. ricks.html accessed on 3 April 2009.

${ }^{72}$ US Army, FM3-24, p. 41.

73 Ibid. 
In August 2000, for instance, General Sir Charles Guthrie, then Chief of the Defence Staff (CDS), said in an interview that "too many humanitarian missions could turn the professional British Army into a "touchy-feely" organisation, more concerned with widows and orphans than fighting'. The quote may misrepresent the tone of the interview but the sentiments are widely shared, with many 'senior officers' believing that too great an emphasis on PSO [Peace Support Operations] will result in British forces becoming a peacekeeping gendarmerie with a diminished reputation. ${ }^{74}$

Notwithstanding the grumblings of conventional war-fighters, with the reemergence of the liberal interventionist doctrines of the Obama administration, the soldier-scholars are on the ascendance.

Alongside this new form of masculinity, a much more familiar colonial feminism is crucial in advancing a particularly new form of metropolitan warrior femininity. The colonial feminism of today deploys the language of humanitarian rescue. ${ }^{75} \mathrm{~A}$ 'feminized security rhetoric has become commonplace in the administration, so much so that it is typical for an official who gives a speech about American actions in Iraq and Afghanistan or about the US policy of promoting democracy around the world to draw the connection to the pursuit of women's rights. ${ }^{76}$ This colonial feminism even admonishes 'the terrorists' for not picking women. A former Pentagon official complains that 'In the years since [Leila] Khaled's hijackings, women's involvement in Palestinian terrorism has been either inconsistent or invisible. Even after proving their success as hijackers, bombers, and cover for men, women have to remind terrorist leaders of their tactical usefulness. ${ }^{77}$ This colonial feminism is appealing to a new category of women policymakers who pride themselves in a kind of collaborative warrior femininity. These counterinsurgent women not only deploy a gendered analysis in their discussion of counterinsurgency - 'these type of operations require very perceptive and deep emotional IQs', and 'women have a more collaborative style' - but also use feminist justifications for their involvement: 'we aren't going to win by telling half the population they can't play'. ${ }^{78}$

The counterinsurgent women have been particularly crucial in creating or sustaining the 'humanitarian' elements of the War on Terror. The Human Terrain System, for example, was originally conceived by a counterinsurgent woman, Montgomery McFate, who wrote her doctoral thesis in cultural anthropology on British counterinsurgency in Northern Ireland, and who was for a while a highly visible figure, both as target of US anthropologists' anger, and as a fashionable and über-feminine policy wonk ${ }^{79}$ who idolises military men - she even anonymously

${ }_{74}^{74}$ Hills, 'Hearts and Minds', p. 5.

75 Lila Abu-Lughod, 'Do Muslim Women Really Need Saving? Anthropological Reflections on Cultural Relativism and Its Others', American Anthropologist, 104 (2002), pp. 783-90; Charles Hirschkind and Saba Mahmood, 'Feminism, the Taliban, and the Politics of Counter-Insurgency', Anthropological Quarterly, 75 (2002), pp. 107-22; Laura Shepherd, 'Veiled References: Constructions of Gender in the Bush Administration Discourse on the Attacks on Afghanistan Post-9/11', International Feminist Journal of Politics, 8 (2006), pp. 19-41.

${ }^{76}$ Michaele Ferguson, "W" Stands for Women: Feminism and Security Rhetoric in the Post-9/11 Bush Administration', Gender and Politics, 1 (2005), p. 18; also Margaret Denike, 'The Human Rights of Others: Sovereignty, Legitimacy, and "Just Causes" for the "War on Terror", Hypatia, 23 (2008), pp. 95-121.

77 Stack-O'Connor, 'Picked Last', p. 97.

78 Ackerman, 'Women'.

79 Matthew Stannard, 'Montgomery McFate's Mission: Can one Anthropologist Possibly Steer the Course in Iraq?', San Francisco Chronicle (29 April 2007). 
ran a blog titled iluvamaninauniform. McFate, in becoming a fellow at the Office of Naval Research, shed her nose-ring, "realizing "there were certain semiotic cues" that would unnerve "paranoidal old white men". ${ }^{80}$ She found no contradiction between her awareness of the gender differences of 'old white men' and 'counterinsurgent women' and the particularly militarist role that she envisioned for social scientists.

As significant are the new category of women security scholars who circulate between the domains of academy, think tanks and the policymaking world. Some of these women have been prominent over the last decade. Sarah Sewall is, in addition to having formerly headed the Carr Center for Human Rights at Harvard University and having been the Deputy Assistant Secretary of Defense for Peacekeeping during the Clinton administration, has authored the foreword to the US Army and Marine Corps Counterinsurgency Field Manual. ${ }^{81}$ Samantha Power, a strong advocate of humanitarian military intervention and the author of a book about Rwanda is currently advisor and speech-writer for President Barak Obama, and was involved in drafting his controversial Nobel speech in defence of US counterinsurgency in Afghanistan. Similarly, the authors of the foreword and introduction to the US Army Stability Operations Field Manual are also women, Michèle Flournoy and Janine Davidson respectively. ${ }^{82}$ Flournoy is currently the Deputy Undersecretary of Defense for Policy at the Obama Pentagon and was a founder of Center for a New American Security, an influential security think tank which has been a vocal advocate of counterinsurgency and the home of many mid-level Obama defence officials. Davidson was in the Bush Pentagon's Special Operations and Low-Intensity Conflict and Special Capabilities Directorate and is the first Deputy Assistant Secretary of Defense for Plans in the Obama Pentagon.

Among these women who combine a liberal interventionist ideology with comfort with security-speak, a curious elision of femininity to a kind of heteronormative sexuality is present. The images of the counterinsurgent women shows them as feminine, dressed in ball gowns, kissing their counterinsurgent officers, all the while flaunting their warrior credentials (one counterinsurgent woman has been a former air force pilot, the other a professor at the US Marine Corps University). Others work in the Pentagon in various - and often influential - positions.

They are also increasingly present in the field of military operation. Two women in particular are worth mentioning here: Sarah Chayes, advisor to General McChrystal in Afghanistan, and Emma Sky, advisor to General Odierno in Iraq. Neither women have ever spoken openly about gender, or feminism, or the ways in which their being women may have influenced their work and their political decisions. Yet, they both embody a kind of intersection of particular class, gender, and 'racial' positionings, in a particular imperial context which makes them clear embodiments of the new gender dynamics of counterinsurgency.

Both women come from non-military backgrounds; Chayes the daughter of liberal Democrats who worked closely with President Kennedy; Sky, of a middleclass background which provided her with private secondary education. Before their careers as advisors to the military commanders of Afghanistan and Iraq,

\footnotetext{
${ }^{80}$ Louisa Kamps, 'Army Brat: How Did the Child of Peace-Loving Bay Area Parents Become the Superstar of National Security Circles?', in Elle (2008), pp. 309-11, 360-2.

81 US Army, FM3-24.

${ }^{82}$ Ibid., FM3-07.
} 
Chayes was a journalist, Sky a development specialist working with the British Department for International Development and the British Council. Both received their educations in elite universities (Harvard and Oxford respectively), and both have learned to speak the predominant language of the country in which they are advisors (Sky speaks Arabic and Hebrew; Chayes has had tutoring in Arabic, but has learned Pashto in Afghanistan). Both their previous work has had 'anthropological' elements, requiring close and intimate knowledge of the indigenous people amongst whom they have worked. Both are often described in vocabulary that emphasises their femininity: Chayes is tall and 'stylish'; Sky is 'petite' (but according to Andrew Exum's counterinsurgency blog 'one of those tough, intrepid women the old British Empire excels at producing'). ${ }^{83}$ They both have assumed a kind of a 'drag': While living in Afghanistan, Sarah Chayes decided to wear men's clothing, as a 'lifestyle choice' ${ }^{84}$ On one blog post someone writes about the ease with which Sky changes tires - that manliest of manly tasks. ${ }^{85}$

Both these humanitarian workers, with their backgrounds of privilege and their education, training, and experience in humanitarian development work have become convinced of the good offices of the military. On the one hand, they represent the 'soft' feminised notion of politics: development work, NGO work, reconciliation work, all posts that are often considered soft, emotional, and womanly, and which are all too frequently populated by women also. Yet they both see in the 'new' way of war, that is, the population-centric counterinsurgency Odierno and McCrystal are fighting, a space for their experience. Sky, described as a modern day Gertrude Bell, ${ }^{86}$ sees her advisory job as having a position of influence, and speaks of loving the US Military: 'she thinks the military is better than the country it protects. "That's the way I feel about it - America doesn't deserve its military". 87 Chayes describes the US military as 'public-spirited' and 'doing its darnedest to do the right thing'. ${ }^{88}$ There is even a familiar element of 'screwball romance' in the way the pairs McCrystal-Chayes and Odierno-Sky are portrayed. The women come across as frank and sassy companions who don't hesitate to talk back.

In these pairings, the gendering becomes most clear: if the soldiers on the ground, the working class, racialised, or underprivileged are expected to act according to their station (even if that station is juggled through the imperial reorderings that place a working class white US woman superior to an Iraqi general), the privileged middle - and upper-class officers and policymakers so clearly represented here portray a kind of metropolitan imperial gendering: the

83 Andrew Exum, 'Lady Sky' (28 April 2008) available at: \{http://www.cnas.org/blogs/abumuqawama/ 2008/04/lady-sky.html\} accessed on 21 December 2009.

${ }^{84}$ Sarah Chayes, The Punishment of Virtue: Inside Afghanistan after the Taliban (London: Portobello Books, 2007), p. 107.

${ }^{85}$ See comment at $8: 47$ am at: $\{$ http://www.cnas.org/blogs/abumuqawama/2008/04/lady-sky.html\} accessed on 4 January 2010.

${ }^{86}$ Deborah Haynes, 'Anti-war Briton Emma Sky is helping to reshape Iraq', The Times (13 April 2009).

87 Thomas E. Ricks, The Gamble: General Petraeus and the Untold Story of the American Surge in Iraq, 2006-2008 (London: Allen Lane, 2008), p. 147.

${ }^{88}$ Rachel Maddow, 'Interview with Sarah Chayes, Advisor to General Stanlev McCrvstal in Afghanistan', MSNBC (29 July 2009), available at: $\{$ http://www.msnbc.msn.com/id/32218850\} accessed on 2 September 2009. 
softer masculinity of the soldier-scholar and the tough warrior femininity of the development/counterinsurgent specialist meet comfortably in the middle, serving the empire in the guise of a liberal, even 'progressive', gender positioning.

\section{Conclusion}

In conclusion, the gendered, racialised, and class-inflected hierarchy of power that emerges out of the US era of counterinsurgency in the 21st century, shows the particular ways in which counterinsurgency provides a fertile ground in which a kind of new warrior masculinity regenerates itself through the figure of the soldier-scholar, and the manner in which the self-declared emancipatory feminist project is coopted by the metropolitan power complex in its projection of power and force overseas. This reproduction of resilient and new forms of masculinity and femininity shows not only the flexibility of the machinery of rule, but also the dynamic recreation of power hierarchies throughout. In this (re)ordering, war-like feminism and scholarly soldiering take their place at the top of pyramid of power. Here, a kind of drag allows for a convergence of masculinities and feminisms, whereas a few rungs further down, the imperial grunts themselves are much more ensconced in the traditional warrior masculinities about whom a good deal of lucidly critical scholarship has already been penned. Their masculinity emerges out of a specific complex of class and racial/geopolitical positioning, where national security discourses are unproblematically conjoined to hetero-normative tropes of manliness, courage, and virtue.

Below the 'manly' imperial grunts are the working class white women who in the seam of encounter with the indigenous forces find themselves elevated above the colonised men they are charged to monitor, control or subdue. In their interstitial position they can be rescued as damsels in distress by the hypermasculine Special Forces soldiers. While ambiguous, the empire gives them a pathway to 'climbing' the ragged ladder of social mobility. Racialised women are placed below them in this hierarchy, too troubling to the kinds of social order envisioned in the empire to be named in heroic narratives of imperial rescue. And at the very bottom layer of this pyramid of power are the conquered men and women, their bodies subjected to violence and surveillance, their lives re-engineered to suit urban counterinsurgencies, pacifications, population control, and the winning of hearts and minds. 